J. Dairy Sci. 92:708-719

doi:10.3168/jds.2008-1582

(c) American Dairy Science Association, 2009.

\title{
Evaluating estimates of phosphorus maintenance requirement of lactating Holstein cows with different dry matter intakes
}

\author{
Z. H. Myers ${ }^{1}$ and D. K. Beede ${ }^{2}$ \\ Department of Animal Science, Michigan State University, East Lansing 48824
}

\begin{abstract}
The objective was to evaluate estimates of the inevitable fecal loss component of the $\mathrm{P}$ maintenance requirement of lactating Holstein cows consuming differing amounts of a low-P diet. The maintenance requirement for $\mathrm{P}$ is the sum of inevitable (e.g., unavoidable) endogenous fecal $\mathrm{P}$ plus endogenous urinary $\mathrm{P}$ when an animal is fed near its true $\mathrm{P}$ requirement (i.e., zero $\mathrm{P}$ balance). Urinary excretion of $\mathrm{P}$ is normally very low in healthy cattle. Inevitable fecal $\mathrm{P}$ is the main part of the total $\mathrm{P}$ maintenance requirement; it can be expressed as grams of fecal $\mathrm{P} /$ kilogram of dry matter intake (DMI). Twenty-one multiparous lactating Holstein cows ( 55 to $253 \pm 6 \mathrm{~d}$ in milk, range $\pm \mathrm{SD}$; 0 to $171 \pm 64 \mathrm{~d}$ pregnant) with a wide range of pretrial milk yields ( 25.3 to $47.3 \pm 1.23 \mathrm{~kg} /$ cow per day) were selected to achieve a range in DMI and assigned to treatment groups of low, medium, and high DMI. To obtain an even greater range in DMI, rations fed to cows in the low and medium treatment groups were restricted to 75 and $50 \%$ of their pretrial ad libitum intakes, respectively. Dry matter intakes during the experiment averaged 11.3 (low), 15.3 (medium), and 25.1 (high) $\mathrm{kg} /$ cow per d, respectively. All cows were fed the same low-P diet $(0.26 \% \mathrm{P}$, dry basis) throughout the experiment. Phosphorus balances of cows in all treatments were not different from zero and unaffected by DMI. Average daily total inevitable fecal $\mathrm{P}$ excretion was $15.3,18.2$, and $26.3 \mathrm{~g} / \mathrm{cow}$ for low, medium, and high DMI, respectively. Inevitable fecal $\mathrm{P}$ excretion was $1.36,1.19$, and $1.04 \mathrm{~g} / \mathrm{kg}$ of DMI for low, medium, and high and decreased linearly with increasing DMI. The regression equation to estimate inevitable fecal $\mathrm{P}$ excretion across the range of DMI was: $(\mathrm{g} / \mathrm{d})=[0.85 \pm$ $0.070(\mathrm{~g} / \mathrm{d})] \times \operatorname{DMI}(\mathrm{kg} / \mathrm{d})+[5.30 \pm 1.224(\mathrm{~g} / \mathrm{d})] ;\left(\mathrm{R}^{2}\right.$
\end{abstract}

\footnotetext{
Received July 25, 2008.

Accepted October 22, 2008

${ }^{1}$ Current address: Myers Dairy Inc., 3938 Bethel Road, Jonesville,

${ }^{2}$ Corresponding author: beede@msu.edu
} NC 28642.
$=0.90)$. This equation can be used to estimate the inevitable fecal $\mathrm{P}$ component of the total $\mathrm{P}$ maintenance requirement of lactating Holstein cows.

Key words: phosphorus requirement, maintenance requirement, lactating dairy cow

\section{INTRODUCTION}

Accurately estimating the total dietary $\mathrm{P}$ requirement of dairy cows is important to optimize performance and reduce risk of excess manure $\mathrm{P}$ entering the environment from dairy farms. The factorial method was used to estimate P requirements (ARC, 1980; NRC, 2001). The absorbed $\mathrm{P}$ requirement is the sum of requirements for maintenance, milk production, growth, and pregnancy. The total dietary $\mathrm{P}$ requirement is computed by dividing the absorbed requirement by the absorption coefficient (AC) of the particular diet. Different feed ingredients have different $\mathrm{AC}$ values for $\mathrm{P}$ (NRC, 2001); thus, the overall AC may differ for different diets depending upon ingredient composition.

The maintenance requirement for absorbed $\mathrm{P}$ is defined as the inevitable (unavoidable) loss of $\mathrm{P}$ in feces plus the endogenous urinary $\mathrm{P}$ when an animal is fed very near its absorbed (true) $\mathrm{P}$ requirement (NRC, 2001). The inevitable fecal component is by far the largest part of the total $\mathrm{P}$ requirement for maintenance. Roughly two-thirds of this inevitable fecal $\mathrm{P}$ loss is thought to be associated with digestive tract microbial debris (Kincaid and Rodehutscord, 2005). Urinary excretion of $\mathrm{P}$ is typically very small for cows fed close to their true requirement for absorbed $\mathrm{P}$ and low compared with fecal $\mathrm{P}$ excretion in healthy cattle (NRC, 2001; Pfeffer et al., 2005).

The approaches to estimate, and the values reported for, the $\mathrm{P}$ requirement for maintenance of dairy cows vary widely (ARC, 1980; INRA, 1989; NRC, 1989, 2001; Pfeffer et al., 2005). Previously, the daily P requirement for maintenance was expressed as milligrams per kilogram of BW (ARC, 1980; INRA, 1989; NRC, 1989). The ARC (1980) suggested that the net or absorbed $\mathrm{P}$ requirement for maintenance was $12 \mathrm{mg}$ of $\mathrm{P} / \mathrm{kg}$ of BW per day. This estimate was based on experimental data of fecal P excretion extrapolated to zero P intake. 
Based on the ARC (1980) approach, the NRC (1989) estimated the total dietary requirement of $\mathrm{P}$ for maintenance as: $\mathrm{g} / \mathrm{d}=[0.0143 \times \mathrm{BW}(\mathrm{kg})] \div 0.50$, where the denominator is an estimate of the $\mathrm{AC}$ for $\mathrm{P}$ in the overall diet. The Institut National de la Recherche Agronomique (INRA, 1989) stated that the P maintenance requirement of $12 \mathrm{mg}$ of $\mathrm{P} / \mathrm{kg}$ of $\mathrm{BW}$ per day reported by ARC (1980) was too low and suggested that the $\mathrm{P}$ maintenance requirement was between 23 to 32 $\mathrm{mg}$ of $\mathrm{P} / \mathrm{kg}$ of $\mathrm{BW}$ per day for cows producing between 5 and $50 \mathrm{~kg}$ of milk/d. Also, the AFRC (1991) noted that the previous research (ARC, 1980) estimated P maintenance requirements for growing and nonlactating animals in which BW and DMI were correlated highly. The AFRC (1991) challenged that this may not an adequate representation of the maintenance requirement for $\mathrm{P}$ of mature lactating dairy cows. A lactating cow has varying feed intake through its lactation cycle, but relative $\mathrm{BW}$ change may not be as great as that of a growing animal during its total growth phase. However, a lactating cow may have a greater relative maintenance requirement for $\mathrm{P}$ because of greater digestive, absorptive, and physiologic demands associated with milk production. Therefore, the AFRC (1991) estimated the $\mathrm{P}$ maintenance requirement as: $(\mathrm{g} / \mathrm{d})=0.693 \times \mathrm{DMI}$ $(\mathrm{kg} / \mathrm{d})-0.06$; in this case, the requirement was equal to the daily inevitable fecal $\mathrm{P}$ excretion. The AFRC (1991) did not include endogenous urinary $\mathrm{P}$ in its estimate of the $\mathrm{P}$ maintenance requirement. Moreover, this equation was developed with data from sheep, but used for lactating cows because insufficient data were available from cattle. This may affect the relevance of the estimate for lactating dairy cows.

Subsequently, Spiekers et al. (1993), using the AFRC (1991) approach, estimated inevitable fecal P loss in an experiment with high- versus low-yielding cows (5 per group) with similar BW but different DMI [17 (high) vs. 11 (low) $\mathrm{kg} /$ cow per day) and MY [21 (high) vs. 10 (low) $\mathrm{kg} / \mathrm{cow}$ per day]. The 2 groups were fed the same diet with $0.21 \% \mathrm{P}$, dry basis. Phosphorus intakes differed (37 vs. $22 \mathrm{~g} /$ cow per day for high and low, respectively) between the groups. Inevitable fecal P loss or the fecal component of the maintenance requirement for $\mathrm{P}$ as a function of feed intake rate was estimated to be 1.20 and $1.22 \mathrm{~g}$ of $\mathrm{P} / \mathrm{kg}$ of DMI for the high and low intake groups, respectively. The theoretical assumptions of this estimation approach are that cows are fed very near their total true (absorbed) $\mathrm{P}$ requirement $(\mathrm{g} / \mathrm{d})$ and that the AC of dietary $\mathrm{P}$ is very near $100 \%$. However, the productivity of the cows in the study of Spiekers et al. (1993) was much less than that of many modern dairy cows.

Recent summaries of much of the world literature on ruminal availability and whole-tract absorbability (e.g., AC) of $\mathrm{P}$ in cattle strongly suggest that values of each are commonly greater than $90 \%$ when dietary $\mathrm{P}$ is fed near the animal's true or net requirement for $\mathrm{P}$ (Kincaid and Rodehutscord, 2005; Pfeffer et al., 2005).

Utilizing the approach and results of Spiekers et al. (1993) as a basis, the NRC (2001) differed somewhat and set the inevitable fecal component of the absorbed $\mathrm{P}$ requirement for maintenance of nonlactating pregnant and lactating cows at $0.8 \mathrm{~g} / \mathrm{kg}$ of DMI plus a small amount of endogenous urinary P $(0.002 \mathrm{~g} / \mathrm{kg}$ of $\mathrm{BW})$. Following a somewhat conservative approach as an example, NRC (2001) illustrated that if the AC of dietary $\mathrm{P}$ was 0.8 , then $1.0 \mathrm{~g} / \mathrm{kg}$ of DMI of dietary $\mathrm{P}$ would be needed to provide the inevitable fecal $\mathrm{P}$ fraction of the total dietary maintenance requirement. Obviously, the actual dietary $\mathrm{P}$ requirement to meet the inevitable fecal $\mathrm{P}$ loss is dependent on the $\mathrm{AC}$ of $\mathrm{P}$ from that particular diet. Presumably correct conceptually, NRC (2001) proposed AC estimates of P for some feeds drawing on the available literature. However, estimation of the dietary $\mathrm{P}$ requirement remains imperfect, in part, because of unknown and perhaps variable $\mathrm{AC}$ among typical feed ingredients. Nonetheless, the inevitable fecal P loss is the largest portion of the absorbed and dietary $\mathrm{P}$ requirements for maintenance.

The objective of the current experiment was to compare new results with earlier estimates of inevitable fecal $\mathrm{P}$ excretion and the $\mathrm{P}$ maintenance requirement using lactating dairy cows with a much wider range of DMI and milk yield than had been studied previously, and to assess the approach taken by NRC (2001).

\section{MATERIALS AND METHODS}

\section{Design, Cows, Treatments, and Diet}

The Michigan State University All-University Committee on Animal Use and Care approved methods for care and use of the cows. Twenty-one lactating Holstein cows were selected to provide 7 cows for each treatment group; treatment groups initially were classified as cows in early $(55 \pm 6.5 \mathrm{DIM})$, mid $(164 \pm 6.0 \mathrm{DIM})$, or late $(253 \pm 6.0$ DIM) lactation. Groups with different DIM were chosen empirically to provide differences in ad libitum feed intakes.

A diet was formulated to supply $\mathrm{P}$ at or below the cows' true $\mathrm{P}$ requirements so that we would be able to measure inevitable fecal P excretion (NRC, 2001); it was formulated to contain $0.24 \% \mathrm{P}$ and was $0.26 \% \mathrm{P}$ (dry basis) when analyzed. The diet met or exceeded requirements for all other nutrients (Table 1). Once treatments were assigned, all cows were fed this same diet for the duration of the experiment. Cows were fed their rations once daily at approximately $1000 \mathrm{~h}$. 
The experiment lasted for $35 \mathrm{~d}$ and consisted of a 6-d pretrial period, a 24-d diet adaptation period (d 7 through 30), and a 5-d collection period. The first 6 -d pretrial period was used to determine if treatment groups, as defined by DIM, would meet the objective of having a wide range of ration ad libitum DMI.

At the end of the 6-d pretrial period, it was determined that the range in DMI of cows within the 3 treatment groups was narrower than desired [20.6, 20.7, and 21.8 $\pm 0.86 \mathrm{~kg} / \mathrm{d}$ for early-, mid-, and late-lactation groups, respectively $(P=0.53)]$. During the pretrial period, milk yield (MY) [47.3, 29.1, and $25.3 \pm 1.23 \mathrm{~kg} /$ cow per $\mathrm{d}$ for early, mid, and late lactation groups, respectively $(P<0.01)]$ was affected by DIM. A primary aim was to increase the range in DMI among the 3 treatment groups. Therefore, the DMI needed to supply enough dietary $\mathrm{NE}_{\mathrm{L}}$ to support the average $\mathrm{MY}$ of each cow recorded during the 6 -d pretrial period was calculated for the mid- and late-lactation treatment groups. The DMI needed to supply adequate energy was about $75 \%$ of ad libitum intake determined during the pretrial period. This restricted intake of mid- and late-lactation treatment groups still did not produce the desired range in DMI, and MY was similar numerically. Therefore, cows in the late-lactation group were restricted an additional $25 \%$ of their 6-d pretrial ad libitum DMI to widen the range of DMI. The final treatments based on targeted DMI were low, 11.3; medium, 15.3; and high, $25.1 \pm 0.74$ $\mathrm{kg} / \mathrm{cow}$ per day when the sample collections started on d 30 (Table 2). Targeted DMI was accomplished by a stepwise reduction in ration offered from $\mathrm{d} 7$ through 11 of the experiment; these daily amounts were offered and completely consumed by cows in low and medium treatments for the remainder of the experiment. Cows in the early-lactation group (highest MY; high treatment) were allowed to continue ad libitum consumption throughout the experimental period to maximize DMI. Therefore, DMI as the definition of the treatments, expressed as a percentage of the average daily ad libitum intake of each individual cow during the pretrial period was $50 \%$ (low), $75 \%$ (medium), and 100\% (high). Body weight and BCS (Wildman et al., 1982) measurements were taken by 2 independent observers on the first and last days of the 35-d experimental period.

\section{Experimental Procedures and Sample Collections}

Chromium oxide was used as an external marker to estimate daily fecal excretion. An initial dose of $45 \mathrm{~g}$ was given orally via balling gun in 2 equal amounts of $22.5 \mathrm{~g}$ at 0600 and $1800 \mathrm{~h}$ in lock ring gelatin capsules (Torpac Inc., Fairfield, NJ) on d 25 of the experiment. The initial dose of $45 \mathrm{~g}$ was given to help ensure that a steady state concentration of $\mathrm{Cr}$ was reached before
Table 1. Formulated ingredient and analyzed chemical composition of the basal diet

\begin{tabular}{lc}
\hline & \% of \\
Item & dietary DM \\
\hline Ingredient & \\
Alfalfa silage & 11.4 \\
Corn silage & 19.3 \\
Beet pulp pellets, dehydrated without molasses & 25.0 \\
Whole cottonseed & 11.0 \\
Corn starch & 10.9 \\
Corn, dry ground & 13.4 \\
Soybean meal, $44 \%$ CP & 3.9 \\
Blood meal & 1.3 \\
Corn oil & 0.1 \\
Limestone & 0.8 \\
White salt (NaCl) & 0.4 \\
Urea & 0.7 \\
Biuret ${ }^{1}$ & 0.8 \\
Vitamin and mineral premix ${ }^{2}$ & 1.0 \\
Chemical composition ${ }^{3}$ & \\
DM & 58.9 \\
CP & 20.3 \\
NE ${ }_{\mathrm{L}}{ }^{4} \mathrm{Mcal} / \mathrm{kg}$ & 1.69 \\
ADF & 21.7 \\
NDF & 39.0 \\
Ash & 3.8 \\
Ca & 0.94 \\
P & 0.26 \\
Mg & 0.22 \\
K & 0.95 \\
Na & 0.39 \\
S & 0.36 \\
Cu, mg/kg & 0.19 \\
Fe, mg/kg & 20 \\
Mn, mg/kg & 346 \\
Zn, mg/kg & 82 \\
\hline & 83 \\
\hline & \\
\hline
\end{tabular}

${ }^{1}$ Graciously provided by Moorman's Manufacturing Company (Quincy, IL).

${ }^{2}$ Trace mineral and vitamin base mix was $71.4 \%$ dry ground corn, $25.5 \%$ vitamin and mineral premix, and $3.1 \%$ corn oil. Concentrations of minerals and vitamins were $0.05 \% \mathrm{Ca}, 0.28 \% \mathrm{P}, 0.60 \% \mathrm{Mg}, 3.3 \%$ $\mathrm{K}, 1.4 \% \mathrm{~S}, 0.01 \% \mathrm{Na}, 332 \mathrm{mg} / \mathrm{kg} \mathrm{Cu}, 699 \mathrm{mg} / \mathrm{kg}$ of $\mathrm{Mn}, 894 \mathrm{mg} / \mathrm{kg}$ of Zn, $90 \mathrm{mg} / \mathrm{kg}$ of Fe, $4 \mathrm{mg} / \mathrm{kg}$ of Co, $7 \mathrm{mg} / \mathrm{kg}$ of Se, $8 \mathrm{mg} / \mathrm{kg}$ of I, $24 \mathrm{kIU} / \mathrm{kg}$ of vitamin A, $5 \mathrm{kIU} / \mathrm{kg}$ of vitamin D, and $0.09 \mathrm{kIU} / \mathrm{kg}$ of vitamin E, dry basis.

${ }^{3}$ Nutrient composition was determined by Dairy One Forage Laboratory (Ithaca, NY), except for $\mathrm{P}$ and ash, which were determined in our research laboratory as described in Materials and Methods.

${ }^{4}$ Energy value estimated based on computation per NRC (2001).

fecal sample collections. On d 26 through 35, cows were given chromium oxide orally in capsules (Torpac Inc.) via balling gun in 2 equal doses of $7.5 \mathrm{~g}$ at 0600 and $1800 \mathrm{~h}$ so that a total of $15 \mathrm{~g} / \mathrm{d}$ was supplied. Approximately $1 \mathrm{~g}$ of hulls of spelt (a subspecies of common wheat, Triticum spelta) was added into the gelatin capsules with the chromium oxide to provide buoyancy to the capsule in the rumen liquor until it dissolved (Oba and Allen, 2000). Spelt hulls contained 0.22\% P and contributed only about $53 \mathrm{mg}$ of dietary $\mathrm{P}$ over the entire 11-d dosing period; therefore, $\mathrm{P}$ supplied by spelt hulls was ignored in P-related calculations of the data. 
Table 2. Performance characteristics and lactational performance of cows as influenced by experimental treatments ${ }^{1}$

\begin{tabular}{|c|c|c|c|c|c|c|c|}
\hline Item & \multicolumn{3}{|c|}{ Treatment $^{2}$} & SEM & \multicolumn{3}{|c|}{$P$-value ${ }^{3}$} \\
\hline Cows, $\mathrm{n}$ & 7 & 7 & 5 & - & - & - & - \\
\hline BCS & 3.3 & 2.5 & 2.1 & 0.19 & $<0.01$ & $<0.01$ & 0.04 \\
\hline DIM & 285 & 169 & 85 & 6.6 & $<0.01$ & $<0.01$ & $<0.01$ \\
\hline DMI, $\mathrm{kg} / \mathrm{d}$ & 11.3 & 15.3 & 25.1 & 0.74 & $<0.01$ & $<0.01$ & NS \\
\hline Milk yield, $\mathrm{kg} / \mathrm{d}$ & 15.7 & 23.9 & 47.0 & 1.56 & $<0.01$ & $<0.01$ & NS \\
\hline $\mathrm{ECM},^{5} \mathrm{~kg} / \mathrm{d}$ & 15.7 & 23.5 & 50.6 & 1.87 & $<0.01$ & $<0.01$ & NS \\
\hline Milk fat, $\%$ & 3.69 & 3.51 & 4.17 & 0.254 & NS & NS & NS \\
\hline Milk protein (true), \% & 2.94 & 2.88 & 3.04 & 0.062 & NS & NS & NS \\
\hline Milk lactose, \% & 4.69 & 4.65 & 4.72 & 0.064 & NS & NS & NS \\
\hline $\mathrm{SNF}, \%$ & 8.60 & 8.49 & 8.78 & 0.118 & NS & NS & NS \\
\hline $\mathrm{SCC}, \times 1,000$ cells $/ \mathrm{mL}$ & 271 & 286 & 191 & 74.3 & NS & NS & NS \\
\hline
\end{tabular}

${ }^{1}$ Values are least squares means. Two cows were removed from the high treatment; one died of causes unrelated to the experiment during the sample collection period and the second was determined to be an outlier $( \pm 3 \mathrm{SD})$ in $\mathrm{P}$ balance. Their data were subsequently removed from all analyses.

${ }^{2}$ Treatments: low $=50 \%$ of pretrial ad libitum intake; medium $=75 \%$ of pretrial ad libitum intake; and high $=100 \%$ ad libitum intake.

${ }^{3}$ Significant effects $(P<0.05)$ and tendencies $(P<0.10)$.

${ }^{4} \mathrm{NS}=$ not significant: $P>0.10$.

${ }^{5} \mathrm{ECM}=$ energy-corrected milk yield $(\mathrm{MY})(\mathrm{kg} / \mathrm{d})=([0.3246 \times \mathrm{MY}(\mathrm{lb} / \mathrm{d})]+[12.86 \times$ milk fat yield $(\mathrm{lb} / \mathrm{d})]+[7.04 \times$ milk protein yield $(\mathrm{lb} / \mathrm{d})])$ $\div 2.2(\mathrm{~kg} / \mathrm{lb})$ (Dairy Record Management Systems, 1999).

Approximately $500 \mathrm{~g}$ of feces (rectal grab samples) was collected in plastic containers with snap-on lids (Sweetheart Cup Company Inc., Chicago, IL) starting on d 31 at 0600 h. Fecal grab samples were collected every $15 \mathrm{~h}$ through $1500 \mathrm{~h}$ on d 35 to account for diurnal variation in fecal chromium oxide and $\mathrm{P}$ excretion. A total of 8 samples were collected from each cow, representing every $3 \mathrm{~h}$ of the 24 -h clock. Fecal samples were frozen $\left(-4^{\circ} \mathrm{C}\right)$ for later processing and analyses of $\mathrm{P}, \mathrm{Cr}$, and DM. Grab samples of urine were taken via manual stimulation of the area around the vulva during the same time as collection of fecal samples. Approximately $100 \mathrm{~mL}$ of urine was collected into a $150-\mathrm{mL}$ graduated screw-top urine specimen container and frozen at $-4^{\circ} \mathrm{C}$ for later processing, and $\mathrm{P}$ and specific gravity analyses. Urine samples were missed occasionally because of a cow's failure to urinate with manual stimulation, but at least 6 of the 8 samples per cow were available for compositing and analyses.

Cows were milked twice daily at 0400 and $1400 \mathrm{~h}$. Two milk samples (25-mL each) per cow were collected at each milking during the 5 -d collection period into sample vials containing a potassium dichromate pellet. One milk sample was for analysis of percentages of milk fat, true protein, lactose, SNF, and SCC (Michigan DHIA, East Lansing). The second milk sample was frozen $\left(-4^{\circ} \mathrm{C}\right)$ for later analysis of $\mathrm{P}$ concentration.

Corn and alfalfa silages were sampled twice weekly for determination of DM concentration via Koster tester (Seedburo Equipment Co., Chicago, IL). As necessary, adjustments were made in the as-fed amounts of forages in the diet to ensure the same DM proportions of all dietary ingredients throughout the experiment. Weekly samples of alfalfa and corn silage also were frozen $\left(-4^{\circ} \mathrm{C}\right)$ for later laboratory analyses of DM and nutrient concentrations. Bagged feed ingredients (concentrates and beet pulp pellets) were sampled twice a week and stored in sealed plastic bags $\left(-4^{\circ} \mathrm{C}\right)$ for later analysis of DM concentration and nutrient composition. Bulk ingredients (whole cottonseed and vitamin and trace mineral premix) were sampled weekly, stored in sealed plastic bags, and frozen $\left(-4^{\circ} \mathrm{C}\right)$ for later analysis.

\section{Feed and Fecal Analyses}

After completion of the sample collection, feed and fecal samples were thawed to room temperature, dried in a forced-air oven $\left(52^{\circ} \mathrm{C}\right)$ for $48 \mathrm{~h}$ to a constant weight for determination of DM content, and then ground successively through 5 - and 2-mm screens in a ThomasWiley mill (Arthur H. Thomas Co., Philadelphia, PA). Feed samples were combined by ingredient type by taking a 5-g aliquot from each sample and combining into one composite sample stored in capped plastic containers. The composite sample represented the average composition of the ingredient used throughout the experiment. A subsample of each composite was analyzed for nutrient composition (Dairy One Forage Laboratory, Ithaca, NY). Composite fecal samples (40 $\mathrm{g}$ each) were made from the 8 individual daily samples 
from each cow and stored in capped plastic containers for subsequent analyses.

Phosphorus concentrations in feed and feces were measured by colorimetric assay adapted from AOAC (1990; method 965.17). All laboratory glassware was acid-washed before use. Duplicate 1-g subsamples of individual feed and fecal composites were taken after thorough mixing and dry-ashed at $600^{\circ} \mathrm{C}$ for $4 \mathrm{~h}$. The resulting ash was digested in $20 \mathrm{~mL}$ of $4 N \mathrm{HCl}$ plus 5 drops of concentrated $\mathrm{H}_{2} \mathrm{SO}_{4}$. Molybdovanadate reagent was added to a 1-mL aliquot of the digested sample to react with $\mathrm{P}$ for color development. Duplicate samples were transferred by pipette into 96-well microtiter plates and $\mathrm{P}$ concentration was determined by using a spectrophotometer (SpectraMax 190, Molecular Devices, Sunnyvale, CA). Samples were read at a wavelength of $400 \mathrm{~nm}$ with a standard curve $(0,0.5$, $1.0,1.5$, and $2.0 \mathrm{mg}$ of $\mathrm{P} / \mathrm{dL}$ ). The standard curve solutions contained the same volumes and proportions of reagents and deionized, distilled water as the samples. The $0 \mathrm{mg} / \mathrm{mL} \mathrm{P}$ standard was used as a blank to adjust the spectrophotometer for any background $\mathrm{P}$ present in the reagents or water used in the digestion or assay processes. New subsamples from the composite were redigested and assayed if the coefficient of variation (CV) between duplicates of the sample was greater than $3 \%$. If the $\mathrm{P}$ concentration of the unknown sample was apparently greater than the greatest concentration of the standard curve, the unknown was diluted 1:20 with deionized, distilled water and reassayed.

Two known controls were included in each assay. One control was a composite fecal sample (pooled sample) comprising $8 \mathrm{~g}$ each from 10 individual-cow fecal sample composites. The pooled sample of constant $\mathrm{P}$ concentration was used in each run of the digestion and assay processes to calculate overall intra- and interassay CV for all plates read on the spectrophotometer. For all assays of fecal samples in the experiment, the intra- and interassay CV were 0.72 and $2.22 \%$, respectively.

A second known control was a $1.0 \mathrm{mg} / \mathrm{dL}$ certified standard P solution (Fisher Scientific, Chicago, IL). This solution was assayed along with unknowns to evaluate the assay-to-assay variation of the spectrophotometer. The intra- and interassay CV among all assays were 0.58 and $1.20 \%$, respectively.

Chromium concentration in feces was analyzed by flame atomic absorption spectroscopy (SpectrAA 220, Varian Inc., Walnut Creek, CA) using a method adapted from Williams et al. (1962). Duplicate 1-g subsamples were taken from fecal composites after thorough mixing and dry-ashed at $600^{\circ} \mathrm{C}$ for $4 \mathrm{~h}$. Resulting ash was then digested on a hot plate in a phosphoric acid, manganese sulfate, and potassium bromate solution at $400^{\circ} \mathrm{C}$ for approximately $10 \mathrm{~min}$. Chromium concentration was determined using a standard curve $(1,2,3,4$, and $5 \mu \mathrm{g}$ of $\mathrm{Cr} / \mathrm{dL}$ ). The standard curve solutions contained the same volume and proportions of reagents and deionized, distilled water as the sample unknowns. A $0 \mu \mathrm{g}$ of $\mathrm{Cr} / \mathrm{dL}$ blank sample was used to adjust the atomic absorption spectrometer for any background Cr present in reagents and water used in the digestion or assay procedures. This solution contained the same reagents and volumes as the unknowns. Unknowns were retested beginning with subsampling for the dry-ashing step if the CV between duplicates was greater than $5 \%$.

For Cr analyses 2 known controls were included in each assay. The intra- and interassay $\mathrm{CV}$ were 2.26 and $4.44 \%$, respectively. The second known control was a $3 \mathrm{mg} / \mathrm{mL}$ Cr solution made from certified chromium oxide powder (Fisher Scientific). This control was used to evaluate the assay-to-assay variation of the atomic absorption spectrometer. The intra- and interassay variations of the spectrometer with the $\mathrm{Cr}$ control solution were 2.65 and $6.9 \%$, respectively.

\section{Urine Sample Analysis and Excretion}

After the conclusion of sample collection, urine samples were thawed to room temperature and $10 \mathrm{~mL}$ was pooled from each of 6 to 8 urine grab samples. Composite samples for $\mathrm{P}$ and specific gravity analyses were acidified with $1 \mathrm{~mL}$ of concentrated $\mathrm{HCl}$, and filtered through cheesecloth to remove any large particulate matter. Specific gravity of each composite was measured using an Adams Midget urinometer (BristolMyers Squib Company, New York, NY). The specific gravity value was used to estimate total daily urine excretion, $\mathrm{kg} / \mathrm{d}=3320.91+(0.3885 \times \mathrm{DMI}, \mathrm{kg} / \mathrm{d})$ $-(0.2175 \times \mathrm{MY}, \mathrm{kg} / \mathrm{d})-(0.083 \times$ dietary $\mathrm{DM} \%)$ $+(0.524 \times$ dietary $\mathrm{CP}, \%$ of $\mathrm{DM})-(326.5 \times$ urine specific gravity $)+(0.2375 \times$ apparently absorbed water, $\mathrm{kg} / \mathrm{d}$ ), as described by Holter and Urban (1992), where apparently absorbed water equals feed water intake $(\mathrm{kg} / \mathrm{d})$ plus drinking water intake $(\mathrm{kg} / \mathrm{d})$ minus fecal water excretion $(\mathrm{kg} / \mathrm{d})$. Drinking water intake $(\mathrm{kg} / \mathrm{d})$ was predicted by the equation: $-10.34+0.2296 \times$ dietary DM $(\%)+2.212 \times$ DMI $(\mathrm{kg} / \mathrm{d})+0.03944 \times$ dietary CP (\% of DM) $)^{2}$ (Holter and Urban, 1992).

Urine $\mathrm{P}$ concentration was determined by colorimetric assay adapted from Fiske and Subbarow (1925). Duplicate 1-mL subsamples were taken from composites and $2 \mathrm{~mL}$ of $20 \%$ TCA was added. The sample was then centrifuged at $4,000 \times g$ for $15 \mathrm{~min}$. A $175-\mu \mathrm{L}$ aliquot of supernatant was used for determination of $\mathrm{P}$ concentration. A molybdate plus amino-napthol-sulfonic acid reagent was used for color development, with color intensity increasing as $\mathrm{P}$ concentrations increased. The $\mathrm{P}$ concentration of urine was determined at $660 \mathrm{~nm}$ with 
a standard curve $(0,0.25,0.5,0.75,1.0$, and $1.25 \mathrm{mg}$ of $\mathrm{P} / \mathrm{dL}$ ) by using a SpectraMax 190 spectrophotometer (Molecular Devices). The standard curve solutions contained the same volume and proportions of reagents and deionized, distilled water as the samples. The 0 $\mathrm{mg} / \mathrm{mL} \mathrm{P}$ standard was used as a blank to adjust the spectrophotometer for any background $\mathrm{P}$ present in the reagents or water. Urine samples were retested if the CV between duplicates was greater than 10\%. Additionally, if the $\mathrm{P}$ concentration of urine was apparently greater than the greatest concentration of the standard curve, an aliquot of the original urine sample composite was diluted 1:6 with deionized, distilled water and reassayed.

A pooled sample of urine as a known control was made by compositing 5 -mL aliquots from 6 individual urine composites. Duplicate 1-mL pooled urine sample aliquots were treated as unknowns in each separate assay to evaluate the variation in the spectrophotometer from assay-to-assay and to calculate the intra- and interassay CV. The intra- and interassay CV were 4.8 and $11.3 \%$, respectively.

\section{Milk Sample Analysis}

After the conclusion of the sample collection period milk samples were thawed in a water bath $\left(40^{\circ} \mathrm{C}\right)$ and mixed thoroughly by inversion and shaking. A single 10-g aliquot of whole raw milk was weighed into $150-\mathrm{mL}$ beakers for P analysis. Samples were dried overnight $\left(100^{\circ} \mathrm{C}\right)$ in a forced-air oven and DM concentration of the samples was determined. Once dried, samples were dry-ashed and assayed according to the same protocol as used for the fecal samples described previously except that the standard curve to determine milk $\mathrm{P}$ concentration was $0,0.5,0.75,1.0$, and $1.25 \mathrm{mg}$ of $\mathrm{P} /$ dL. Once milk P percentage (DM basis) was computed it was converted to a wet, raw milk basis. Each milk sample from each cow at each individual milking was analyzed for $\mathrm{P}$ concentration and then a 5-d weighted average was computed for each cow based on MY at each milking. A 5-d weighted average was also computed for percentages of milk fat, true protein, lactose, SNF, and SCC for each cow. Statistics reported are based on the 5-d weighted average for each cow for these dependent variables.

Two separate milk sample pools to serve as known controls were made to digest and assay along with the unknowns. Milk pools were made from $2 \mathrm{~L}$ of milk obtained from a herdmate not in the experiment. A high milk $\mathrm{P}$ pool was a $25-\mathrm{mL}$ aliquot of whole raw milk, and a low milk pool was made by diluting whole raw milk approximately 1:2.5 with water for a total volume of $25 \mathrm{~mL}$. The milk pools were digested and analyzed in duplicate along with the unknowns to estimate intraand interassay CV. The intra- and interassay CV were 1.73 and $6.39 \%$, respectively, for the high pool and 1.70 and $6.18 \%$, respectively, for the low pool.

A third known control was a solution containing 0.80 $\mathrm{mg}$ of $\mathrm{P} / \mathrm{dL}$ made from a purchased $1.0 \mathrm{mg} / \mathrm{dL} \mathrm{P}$ certified standard (Fisher Scientific). This control solution was assayed with the unknowns to provide an estimate of the assay-to-assay variation in the spectrophotometer. The intra- and interassay $\mathrm{CV}$ of this control were 0.56 and $1.02 \%$, respectively.

\section{Statistical Analysis}

Statistical inferences were made using SAS software (SAS Institute, 1999). Prior to ANOVA, the mean, standard deviation, minimum, and maximum values were calculated by the Means procedure for all dependent variables to help validate the data sets. Next, an outlier analysis was conducted using the calculated mean \pm 3 standard deviations of each dependent variable. Based on this analysis one cow in the high treatment had a very negative $\mathrm{P}$ balance for unknown reasons; all of her data for all dependent variables were removed from analyses.

The Mixed Models procedure was used to determine that the residuals of each dependent variable in the data set were distributed normally. This was done using the linear model $\mathrm{X}_{\mathrm{ijk}}=\mu+\mathrm{T}_{\mathrm{i}}+\mathrm{P}_{\mathrm{j}}+\mathrm{T}_{\mathrm{i}} \times \mathrm{P}_{\mathrm{j}}+\mathrm{C}_{\mathrm{k}}$ $\left(T_{i} \times P_{j}\right)+E_{i j k}$, where $X_{i j k}$ is the expected response; $\mu$ is the overall mean; $T_{i}$ is the effect of treatment $i$; $P_{j}$ is the effect of parity $j ; T_{i} \times P_{j}$ is the interaction between treatment $\mathrm{i}$ and parity $\mathrm{j} ; \mathrm{C}_{\mathrm{k}}$ is the random effect of cow $\mathrm{k}$, nested within treatment $\mathrm{i}$ and parity $\mathrm{j}$; and, $\mathrm{E}_{\mathrm{ijk}}$ is the experimental error.

There were 2 parity classifications for this experiment, $\leq$ second parity and $\geq$ third parity. Distribution of residuals was determined by F-test to be normal if $P>0.001$.

Data of dependent variables were also tested for heterogeneity (unequal variances) using the Mixed Procedure (SAS Institute, 1999). The absolute value of the residuals was computed and used to determine heterogeneity. The linear model was $\mathrm{X}_{\mathrm{ik}}=\mu+\mathrm{T}_{\mathrm{i}}+$ $+\mathrm{C}_{\mathrm{j}}\left(\mathrm{T}_{\mathrm{i}}\right)+\mathrm{E}_{\mathrm{ik}}$, where $\mathrm{X}_{\mathrm{ik}}$ is the absolute value of the residual; $\mu$ is the overall mean of the residuals; $T_{i}$ is the effect of treatment i; $C_{k}$ is the random effect of cow $k$, nested within treatment $\mathrm{i}$; and $\mathrm{E}_{\mathrm{ik}}$ is the experimental error.

Cow effect was random and nested within treatment. Variances were determined by F-test to be heterogeneous (unequal) if $P<0.05$.

For ANOVA, statistical significance was declared if $P<0.05$, and tendencies were noted if $P<0.10$. The 
method of least squares ANOVA was used to determine differences among treatment means of each dependent variable by the Mixed Model procedure (SAS Institute, 1999). The linear model used was $X_{i k}=\mu+T_{i}+C_{k}$ $\left(T_{i}\right)+E_{i k}$, where $X_{i k}$ is the response of the dependent variable; $\mu$ is the overall mean; $T_{i}$ is the effect of treatment $\mathrm{i} ; \mathrm{C}_{\mathrm{k}}$ is the random effect of cow $\mathrm{k}$, nested within treatment $\mathrm{i}$; and $\mathrm{E}_{\mathrm{ik}}$ is the experimental error.

Parity and the treatment $\times$ parity interaction were included in the original model, but were inconsequential and omitted in the final model. Orthogonal contrasts (linear and quadratic effect of treatment) were used to compare treatment mean responses.

A major dependent variable of interest relative to the experimental objective was fecal $\mathrm{P}$ excretion $(\mathrm{g} / \mathrm{d})$ divided by DMI $(\mathrm{kg} / \mathrm{d})$. Regression analysis with daily fecal $\mathrm{P}$ excretion as the dependent variable and DMI as the independent variable was done according to SAS software (SAS Institute, 1999). The fit of the model was determined by the coefficient of multiple determination $\left(\mathrm{R}^{2}\right)$ also using the regression procedure. A scatter plot of fecal $\mathrm{P}$ excretion $(\mathrm{g} / \mathrm{d}$, y-axis) versus DMI $(\mathrm{kg} / \mathrm{d}$, $\mathrm{x}$-axis) and the best-fit regression line were plotted.

\section{RESULTS AND DISCUSSION}

\section{Experimental Diet}

Ingredient and analyzed chemical compositions of the experimental diet are in Table 1 . The diet was formulated to be as low as possible in $\mathrm{P}$ concentration. Therefore, it contained $25 \%$ beet pulp pellets (without molasses), similar in energy content to corn silage and alfalfa silage, but with less P (0.08 vs. 0.21 and $0.20 \%$ $\mathrm{P}, \mathrm{DM}$ basis for beet pulp pellets vs. corn silage and alfalfa silage, respectively). Cornstarch replaced a portion of corn grain and soybean meal $(44 \% \mathrm{CP})$ and supplied similar energy, but with less $\mathrm{P}(0.009 \%$, dry basis vs. 0.30 and $0.71 \% \mathrm{P}$ for corn grain and soybean meal, respectively). However, beet pulp pellets and cornstarch did not contain as much CP (8.4 and 0.6\%, DM basis, respectively) as alfalfa silage, corn silage, or corn grain $(20.0,8.5$, or $9.1 \% \mathrm{CP}$, DM basis, respectively). Therefore, urea and biuret were added to supply dietary $\mathrm{CP}$ without adding more P. Formulated $\mathrm{P}$ content of the diet was $0.24 \%$, and the average actual analyzed content based on samples taken throughout the experiment was $0.26 \%$, dry basis.

\section{Characteristics of Cows and Lactation Performance}

Characteristics of the cows and performance variables as influenced by experimental treatments are in Table 2. Differences among treatments in BW, BCS, and DIM of cows resulted from the initial assignment to treatment categories based on DIM and length of time cows had been lactating. Daily DMI expressed as a percentage of $\mathrm{BW}$ was $1.8,2.9$, and $4.2 \%$ for low, medium, and high treatments, respectively $(P<0.02$; quadratic effect). This was the criterion to define treatments and to estimate differences in inevitable fecal $\mathrm{P}$ excretion, the primary component of the $\mathrm{P}$ maintenance requirement.

Apparent dietary DM digestibility of cows differed slightly among treatments (from 68.1 to $70.0 \%$; $P<$ 0.01; linear effect; Table 2). Milk yield (unadjusted for component concentrations) and ECM yield increased with increasing DMI and fewer DIM for cows in high, medium, and low treatments, respectively $(P<0.01$; linear effect). Percentages milk fat, true protein, lactose, SNF, and SCC were not affected by treatment $(P$ $>0.05)$.

\section{Feces, Urine, and Milk}

Characteristics of feces, urine, and milk are summarized in Table 3. Fecal DM percentage tended to decrease slightly $(P=0.09$; linear effect $)$ with increasing DMI. Fecal DM excretion increased linearly $(P<$ $0.01)$ as DMI increased (3.60, 4.61, and $7.63 \mathrm{~kg} / \mathrm{cow}$ per d) for low, medium, and high, respectively. This response would be expected with increased DMI, but apparent DM digestibility was similar among treatments (Table 2). This was similar to results of Spiekers et al. (1993), with 2 groups of 5 cows each in different stages of lactation; DMI differed (17 vs. $11 \mathrm{~kg} /$ cow per d), and fecal DM excretion increased as DMI increased. In the current experiment, there was an inverse relationship between fecal P\% (dry basis) and DMI [0.43, 0.40, and $0.35 \% \mathrm{P}( \pm 0.01$, SEM $)$, dry basis; $P<0.01$; linear effect]. The reason for this relationship is unknown; differences in fecal $\mathrm{P}$ concentration were numerically small among treatments. Total daily fecal $\mathrm{P}$ excretion $(15.3,18.2$, and $26.5 \mathrm{~g} / \mathrm{d}$ for low, medium and high, respectively) increased linearly $(P<0.01)$ with increasing DMI. Cows in all 3 treatments were fed the same diet $(0.26 \% \mathrm{P}$, dry basis). These results differed slightly from those of Spiekers et al. (1993) who reported no difference in fecal $\mathrm{P}$ concentration between treatments (0.48 vs. $0.49 \%$ for high and low DMI, respectively). Nonetheless, similar to the current experiment they reported an increase in daily fecal $\mathrm{P}$ excretion because of increased DMI and fecal DM excretion.

Estimated total urine excretion was 11.4, 14.3, and $21.0 \mathrm{~kg} / \mathrm{d}$ per cow for low, medium, and high, respectively, increasing linearly $(P<0.01)$ with increasing DMI (Table 3). Urine P concentrations on a wet basis were $0.024,0.005$, and $0.003 \mathrm{~g} / \mathrm{kg}$ of urine for low, me- 
Table 3. Characteristics of feces, urine, and milk as influenced by experimental treatments ${ }^{1}$

\begin{tabular}{|c|c|c|c|c|c|c|c|}
\hline Item & \multicolumn{3}{|c|}{ Treatment ${ }^{2}$} & SEM & \multicolumn{3}{|c|}{$P$-value ${ }^{3}$} \\
\hline Fecal DM, \% & 18.3 & 17.6 & 16.6 & 0.58 & $\mathrm{NS}^{4}$ & 0.09 & NS \\
\hline Fecal P. \% of DM & 0.43 & 0.40 & 0.35 & 0.01 & $<0.01$ & $<0.01$ & NS \\
\hline Urine ${ }^{5} \mathrm{~kg} /$ cow per d & 11.4 & 14.3 & 22.0 & 0.93 & $<0.01$ & $<0.01$ & NS \\
\hline Urine $\mathrm{P} \mathrm{g} / \mathrm{kg}$ (wet basis) & 0.024 & 0.005 & 0.003 & 0.03 & NS & NS & NS \\
\hline
\end{tabular}

${ }^{1}$ Values are least squares means.

${ }^{2}$ Treatments: low $=50 \%$ of pretrial ad libitum intake; medium $=75 \%$ of pretrial ad libitum intake; and high $=100 \%$ ad libitum intake

${ }^{3}$ Significant effects $(P<0.05)$ and tendencies $(P<0.10)$.

${ }^{4} \mathrm{NS}=$ not significant: $P>0.10$.

${ }^{5}$ Estimated from equation (Holter and Urban, 1992).

dium, and high DMI, respectively, but not different $(P$ $>0.1$ ). As expected, total daily urine $\mathrm{P}$ excretion was small and did not differ among treatments. These results are similar to those of $\mathrm{Wu}$ et al. (2000) in which there was no difference in urine $\mathrm{P}$ excretion of lactating cows fed diets with 0.31 to $0.49 \% \mathrm{P}$. In other studies, with dietary $\mathrm{P}$ from 0.30 to $0.67 \% \mathrm{P}$, urinary $\mathrm{P}$ excretion increased with increasing dietary $\mathrm{P}$ concentration (Morse et al., 1992; Knowlton and Herbein, 2002). However, urinary $\mathrm{P}$ concentrations in those studies were low and total urinary $\mathrm{P}$ excretion was only 1.8 and $1.7 \mathrm{~g} / \mathrm{cow}$ per day for Knowlton and Herbein (2002) and Morse et al. (1992), respectively.

In the current experiment, milk P concentrations were not different among treatments and overall averaged $0.081 \%$ (Table 3), similar to the results of Knowlton and Herbein (2002), Wu et al. (2000), and Brintrup et al. (1993). Milk $\mathrm{P}$ percentage in these 3 studies ranged from 0.085 to $0.091 \% \mathrm{P}$ when dietary $\mathrm{P}$ ranged from
0.31 to $0.67 \%$, respectively. In the current experiment, the total grams of milk $\mathrm{P}$ secretion increased linearly for low, medium, and high, respectively, because of differences in MY $(P<0.01)$.

\section{Dietary P Utilization}

The apparent efficiency of utilization of dietary $\mathrm{P}$ improved from low, medium, and high treatments, respectively (Table 4). Apparent P digestibility increased linearly $(P<0.01)$, presumably a function of increased demand for $\mathrm{P}$ for functions associated with greater DMI and MY. Total grams of $\mathrm{P}$ apparently absorbed also increased as $\mathrm{P}$ intake increased among treatments $(P$ $<0.01)$. More efficient use of ingested $P$ likely resulted from greater demand of $\mathrm{P}$ driven by greater $\mathrm{MY}$.

As expected, fecal $\mathrm{P}$ excretion as a percentage of total $\mathrm{P}$ excretion was large $(98.4,99.6$, and $99.8 \%$, for low, medium, and high, respectively; linear effect, $P$

Table 4. Dietary P utilization as influenced by experimental treatments ${ }^{1}$

\begin{tabular}{|c|c|c|c|c|c|c|c|}
\hline Item & \multicolumn{3}{|c|}{ Treatment $^{2}$} & SEM & \multicolumn{3}{|c|}{$P$-value ${ }^{3}$} \\
\hline Apparent P digestibility, $\%$ & 47.0 & 54.1 & 59.7 & 1.54 & $<0.01$ & $<0.01$ & $\mathrm{NS}^{4}$ \\
\hline Total $\mathrm{P}$ excretion, $\%$ of $\mathrm{P}$ intake & 53.0 & 45.9 & 40.3 & 1.36 & $<0.01$ & $<0.01$ & 0.04 \\
\hline Fecal P, $\%$ of $\mathrm{P}$ intake & 52.2 & 45.7 & 40.2 & 1.54 & $<0.01$ & $<0.01$ & NS \\
\hline Fecal P, $\%$ of total $\mathrm{P}$ excretion & 98.4 & 99.6 & 99.8 & 0.85 & NS & NS & NS \\
\hline Milk $\mathrm{P}, \%$ of $\mathrm{P}$ intake & 41.9 & 50.7 & 57.6 & 3.38 & 0.02 & $<0.01$ & NS \\
\hline Milk $\mathrm{P}^{5} \%$ of total $\mathrm{P}$ output & 43.4 & 52.3 & 58.8 & 2.33 & $<0.01$ & $<0.01$ & NS \\
\hline
\end{tabular}

${ }^{1}$ Values are least squares means.

${ }^{2}$ Treatments: low $=50 \%$ of pretrial ad libitum intake; medium $=75 \%$ of pretrial ad libitum intake; and high $=100 \%$ ad libitum intake.

${ }^{3}$ Significant effects $(P<0.05)$ and tendencies $(P<0.10)$.

${ }^{4} \mathrm{NS}=$ not significant: $P>0.10$.

${ }^{5}$ Total $\mathrm{P}$ output $=\mathrm{P}$ in feces plus urine, plus milk. 
Table 5. Phosphorus excretion and balance as influenced by experimental treatments ${ }^{1}$

\begin{tabular}{|c|c|c|c|c|c|c|c|}
\hline Item & \multicolumn{3}{|c|}{ Treatment $^{2}$} & SEM & \multicolumn{3}{|c|}{$P$-value ${ }^{3}$} \\
\hline $\mathrm{P}$ intake, $\mathrm{g} / \mathrm{d}$ & 29.4 & 39.8 & 65.2 & 1.93 & $<0.01$ & $<0.01$ & $\mathrm{NS}^{4}$ \\
\hline Fecal P, g/d & 15.30 & 18.20 & 26.35 & 1.16 & $<0.01$ & $<0.01$ & NS \\
\hline Urine $\mathrm{P}, \mathrm{g} / \mathrm{d}$ & 0.26 & 0.07 & 0.06 & 0.14 & NS & NS & NS \\
\hline Milk P, g/d & 12.3 & 20.1 & 37.3 & 1.23 & $<0.01$ & $<0.01$ & NS \\
\hline
\end{tabular}

${ }^{1}$ Values are least squares means.

${ }^{2}$ Treatments: low $=50 \%$ of pretrial ad libitum intake; medium $=75 \%$ of pretrial ad libitum intake; and high $=100 \%$ ad libitum intake.

${ }^{3}$ Significant effects $(P<0.05)$ and tendencies $(P<0.10)$.

${ }^{4} \mathrm{NS}=$ not significant: $P>0.10$.

${ }^{5}$ Total $\mathrm{P}$ excretion, $\mathrm{g} / \mathrm{d}=$ the total maintenance requirement for $\mathrm{P}$.

${ }^{6} \mathrm{P}$ balance, $\mathrm{g} / \mathrm{d}=\mathrm{P}$ intake $(\mathrm{g} / \mathrm{d})-[$ total $\mathrm{P}$ excretion $(\mathrm{g} / \mathrm{d})+$ milk $\mathrm{P}$ secretion $(\mathrm{g} / \mathrm{d})] ; \mathrm{P}$ balance was not different from zero $(P>0.05)$.

${ }^{7}$ Inevitable fecal $\mathrm{P}$ loss, $\mathrm{g}$ of $\mathrm{P} / \mathrm{kg}$ of $\mathrm{DMI}=$ fecal $\mathrm{P}$ excretion $(\mathrm{g} / \mathrm{d}) / \mathrm{DMI}(\mathrm{kg} / \mathrm{d})$, which is the major component of the total maintenance requirement for $\mathrm{P}$.

$<0.01)$; and $\mathrm{P}$ excretion in urine was small $(\leq 1.6 \%$ of total $\mathrm{P}$ excretion among treatments). Milk $\mathrm{P}$ secretion, expressed either as a percentage of $\mathrm{P}$ intake or as a percentage of total $\mathrm{P}$ output in feces, urine, and milk increased in low, medium, and high treatments, respectively (Table 4 ; linear effect; $P<0.01$ ). Increased apparent efficiency of secretion of $\mathrm{P}$ in milk is presumed associated with increasing milk yield. Overall, these results of apparent $\mathrm{P}$ digestibility, excretion profiles, and efficiency of secretion of $\mathrm{P}$ into milk are similar to the relationships generally described for healthy ruminants (NRC, 2001; Pfeffer et al., 2005).

\section{Phosphorus Balance and Excretion}

Phosphorus balance $\{\mathrm{P}$ intake, $\mathrm{g} / \mathrm{d}-[$ fecal $\mathrm{P}$ excretion + urinary $\mathrm{P}$ excretion + milk $\mathrm{P}$ secretion $(\mathrm{g} / \mathrm{d})]\}$ was important for defining that treatments provided for appropriate evaluation of inevitable fecal $\mathrm{P}$ excretion, the primary component of the $\mathrm{P}$ maintenance requirement of lactating dairy cows. Amount of $\mathrm{P}$ associated with gestation was not considered in the $\mathrm{P}$ balance equation because none of the cows in the study were in the last trimester of pregnancy (NRC, 2001). Table 5 summarizes $\mathrm{P}$ intake, excretion, secretion, and balance by treatment. As would be expected, $\mathrm{P}$ intake increased linearly as DMI increased $(29.4,39.8$, and $65.2 \mathrm{~g} / \mathrm{cow}$ per $\mathrm{d}$ for low, medium, and high, respectively; $P<$ 0.01). Also, total $\mathrm{P}$ excretion (fecal $\mathrm{P}+$ urinary $\mathrm{P}$ ) increased linearly $(15.6,18.3$, and $26.4 \mathrm{~g} / \mathrm{d}$ for cows in low, medium, and high, respectively; $P<0.01$ ). Feces is the major route of $\mathrm{P}$ excretion (NRC, 2001), and urinary $\mathrm{P}$ excretion constituted only between 0.04 and $1.6 \%$ of total $\mathrm{P}$ excretion across treatments in the current experiment (Table 4).

\section{Estimation of Inevitable P and Maintenance Requirement}

Average $\mathrm{P}$ balance for cows among the 3 treatments was $1.5 \mathrm{~g} / \mathrm{d}$ and not different $(P>0.1$; Table 5$)$. Phosphorus balances for each treatment also were not different from zero $(P>0.1$; Table 5$)$, indicating that cows consumed $\mathrm{P}$ near their absorbed $\mathrm{P}$ requirement. Because cows consumed amounts of $\mathrm{P}$ that resulted in a $\mathrm{P}$ balance very near zero, the $\mathrm{P}$ excretion in feces and urine is considered primarily inevitable $\mathrm{P}$ loss. Therefore, the $\mathrm{P}$ requirement for maintenance can be estimated from these data (NRC, 2001). Two assumptions are made when estimating the $\mathrm{P}$ maintenance requirement in this way. First, because $\mathrm{P}$ is fed at a low dietary concentration and near the true absorbed requirement, the consumed $\mathrm{P}$ will be utilized (absorbed) with high efficiency (AFRC 1991; NRC 2001; Pfeffer et al., 2005). Second, because most of the dietary $\mathrm{P}$ is assumed absorbed, most of the $\mathrm{P}$ found in feces and all of that in urine is assumed to be of endogenous origin. Much of the $\mathrm{P}$ in feces is assumed to be dietary $\mathrm{P}$ that was absorbed from the digestive tract, recycled via saliva into the rumen, reabsorbed, and (or) at some point excreted in feces. Nearly as much P can be recycled daily by a lactating cow as is consumed in the diet (NRC, 2001). Inevitable fecal $\mathrm{P}$ excretion includes that of endogenous origin, that present in microbial cell debris from the digestive tract, plus any small fraction of unavailable dietary $\mathrm{P}$ excreted in feces. It is estimated that about twothirds of this inevitable fecal $\mathrm{P}$ loss is associated with microbial debris (Kincaid and Rodehutscord, 2005). Moreover, salivary recycling of $\mathrm{P}$ is an innate strategy of ruminants that should be considered part of maintenance because $\mathrm{P}$ is indispensible to support micro- 
bial growth in the rumen (Kincaid and Rodehutscord, 2005), a key virtue for digestion, ruminal microbial protein synthesis, and survival of ruminants. Therefore, counting the $\mathrm{P}$ in feces from microbial cell debris as part of inevitable fecal $\mathrm{P}$ is appropriate and should be considered part of the $\mathrm{P}$ maintenance requirement of lactating cows. This consideration extends beyond the classical factorial definition of the $\mathrm{P}$ requirement that includes only $\mathrm{P}$ that has been absorbed and is "inside" the body, not in the digestive tract lumen. However, the $\mathrm{P}$ requirement of the microbial population in the digestive tract is not taken into account in any other way in current requirement estimates (AFRC, 1991; NRC, 2001). In a practical way, it certainly can be considered part of maintenance for normal digestive function of the ruminant.

In the current experiment, inevitable fecal $\mathrm{P}$ expressed as grams per kilogram of DMI declined with increasing DMI (1.36, 1.19, and 1.04 for low, medium, and high, respectively; linear effect; $P<0.01)$. This may be a reflection of more efficient utilization of absorbed $\mathrm{P}$ by cows yielding greater quantities of milk, especially when fed near their true requirement for absorbed P. Using a similar experimental approach, Spiekers et al. (1993) found that inevitable fecal $\mathrm{P}$ excretion was 1.20 and $1.22 \mathrm{~g} / \mathrm{kg}$ of DMI for lactating cows consuming 17 and $11 \mathrm{~kg}$ of DM/cow per day. Therefore, inevitable fecal $\mathrm{P}$ excretion per kilogram of DMI for cows in the medium treatment of the current experiment was very similar to that of comparable cows in the study of Spiekers et al. (1993).

Additionally, as mentioned previously, a small amount of $\mathrm{P}$ is excreted in urine and is considered part of the $\mathrm{P}$ maintenance requirement because it is part of the absorbed (endogenous) P fraction. The AFRC (1991) acknowledged that urine $\mathrm{P}$ theoretically should be added to inevitable fecal $\mathrm{P}$ for determining the maintenance requirement, but ignored it in the final requirement calculation because of the low amount of $\mathrm{P}$ typically excreted in urine by cattle. However, NRC (2001) added an additional $2 \mathrm{mg}$ of urine $\mathrm{P} / \mathrm{kg}$ of $\mathrm{BW}$ to its estimate of $\mathrm{P}$ maintenance requirement for lactating dairy cows.

Estimated total daily urine $\mathrm{P}$ excretion was small and did not differ among treatments (Table 5). Also, the estimate of urine $\mathrm{P}$ as a function of $\mathrm{BW}$ was very small and not different among treatments (0.1 to 0.4 $\mathrm{mg}$ of $\mathrm{P} / \mathrm{kg}$ of $\mathrm{BW})$. These estimates were an order of magnitude less than the value assumed for endogenous urinary P excretion by NRC (2001) to estimate that fraction of the $\mathrm{P}$ maintenance requirement, although in each case the contribution of urinary $\mathrm{P}$ to the total maintenance requirement is very small. The reasons for our lower estimates could be due to the fact that cows were consuming a diet with quite low $\mathrm{P}$ concentration or the method we used to estimate urine output. However, Spiekers et al. (1993) reported 0.3 g of urinary P/ cow per day with a $0.21 \% \mathrm{P}$ diet, similar to the average quantity of urinary $\mathrm{P}$ excretion of cows in the low treatment in the current study $(0.26 \mathrm{~g} /$ cow per day).

The NRC (2001) conservatively set the inevitable (unavoidable) fecal component of the absorbed $\mathrm{P}$ requirement for maintenance of nonlactating pregnant and lactating cows at $0.8 \mathrm{~g} / \mathrm{kg}$ of DMI. This obviously is a lower value than estimated in the current experiment for cows over a wide range in DMI, or the estimates of Spiekers et al. (1993). Perhaps our new estimates of inevitable fecal $\mathrm{P}$ should more correctly be considered part of the dietary $\mathrm{P}$ requirement for maintenance, not the absorbed $\mathrm{P}$ requirement per se; in this case, a dietary AC would be presumed to approach 1.0. This interpretation is advanced with the understanding that the closer cows are fed to their true absorbed requirement, the greater the $\mathrm{AC}$ will be, approaching 0.9 or greater when experimentally quantified with appropriate techniques (Pfeffer et al., 2005).

Because these new estimates were made over a much wider range of DMI than had previously been evaluated, a regression analysis was done to quantify and better understand the relationship between DMI and inevitable $\mathrm{P}$ loss in feces, and to assess if modification of the estimate of the NRC (2001) was warranted. Inevitable fecal $\mathrm{P}$ excretion $(\mathrm{g} / \mathrm{d})$ was regressed on DMI $(\mathrm{kg} / \mathrm{cow}$ per day) using all of the data collected in our experiment. A linear relationship between inevitable fecal) $\mathrm{P}$ excretion and DMI was found; $(P<0.01$; Figure 1). The equation that described this relationship was: inevitable fecal P excretion, $\mathrm{g} / \mathrm{d}=[0.85 \pm 0.070(\mathrm{~g} / \mathrm{d})]$ $\times$ DMI, $\mathrm{kg} / \mathrm{d}+[5.30 \pm 1.224(\mathrm{~g} / \mathrm{d})]$, in which 0.85 is the slope of the regression line and 5.3 is the y-intercept (Figure 1). Thus, for every 1-kg increase in DMI, an additional $0.85 \mathrm{~g}$ of inevitable fecal $\mathrm{P}$ was excreted. Theoretically, if a cow had a DMI of $0 \mathrm{~kg} / \mathrm{d}$ she would still be expected to excrete $5.30 \mathrm{~g}$ of $\mathrm{P}$ in feces. This relationship explained $90 \%$ of the variation associated with fecal $\mathrm{P}$ excretion with a root mean square error of $1.75 \mathrm{~g} / \mathrm{d}$. Additionally, the y-intercept was different from zero and the slope was different from $1(P<$ 0.01 ). There was more variation in inevitable fecal $\mathrm{P}$ excretion for cows in the high treatment with greater DMI compared with cows in medium and low treatments (Figure 1). Because cows in the high treatment were allowed to consume feed ad libitum there was less control over their $\mathrm{P}$ intake compared with that of cows in low and medium treatments. Therefore, the opportunity may have been greater for cows in the high treatment to consume more dietary $\mathrm{P}$ than their true requirement, increasing fecal $\mathrm{P}$ excretion. When lactat- 


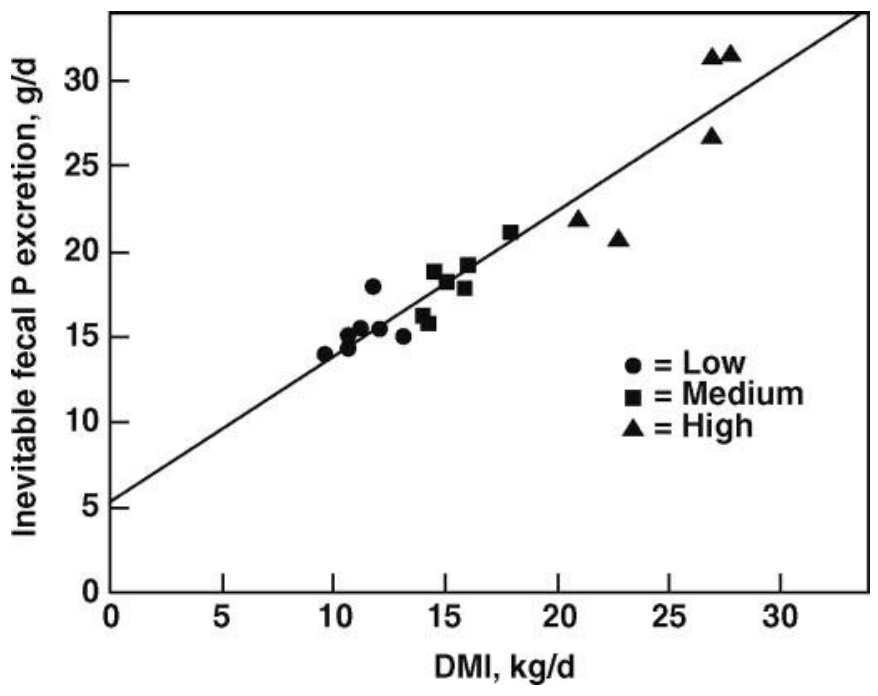

Figure 1. Relationship between inevitable fecal $\mathrm{P}$ and daily DMI: inevitable fecal P $(\mathrm{g} / \mathrm{d})=[5.30 \pm 1.224(\mathrm{~g} / \mathrm{d})]+[(0.85 \pm 0.70) \times$ DMI $(\mathrm{kg} / \mathrm{d})](\mathrm{RMSE}=2.75 ; \mathrm{y}$-intercept different from zero; slope different from $\left.1 ; \mathrm{R}^{2}=0.90 ; P<0.01\right)$. Low $=50 \%$ of pretrial ad libitum intake medium $=75 \%$ of pretrial ad libitum intake; and high $=100 \%$ of ad libitum intake.

ing cows consumed more dietary $\mathrm{P}$ than needed the additional $\mathrm{P}$ was excreted in feces and urine (Martz et al., 1990; Morse et al., 1992; Brintrup et al., 1993; Wu et al., 2000, 2001; Knowlton and Herbein, 2002).

The y-intercept, $5.30 \mathrm{~g} / \mathrm{d}$ of inevitable fecal $\mathrm{P}$ at zero intake, may be considered the more theoretically accurate estimate of that portion of the $\mathrm{P}$ maintenance requirement as defined by ARC (1980). However, this does not have much practical use to estimate the dietary $\mathrm{P}$ maintenance requirement of a lactating cow that is consuming feed and if the $\mathrm{P}$ in fecal microbial debris is considered part of inevitable fecal P. This loss is inevitable and obligatory, especially for an animal fed close to the true requirement for absorbed P. The ARC (1980) suggested that the net or absorbed P requirement for maintenance was $12 \mathrm{mg}$ of $\mathrm{P} / \mathrm{kg}$ of $\mathrm{BW}$ per day. This was based on experimental data of fecal $\mathrm{P}$ excretion extrapolated to zero P intake. Making similar extrapolations from our data, estimates were 8.3, 10.0, and $8.8 \pm 0.35 \mathrm{mg}$ of $\mathrm{P} / \mathrm{kg}$ of $\mathrm{BW}$ for low, medium, and high, respectively $(P<0.01$; quadratic effect).

The final aim of this study was to compare estimates of the total dietary $\mathrm{P}$ maintenance requirement of a lactating dairy cow from the different models-ARC (1980), NRC (1989), INRA (1989), AFRC (1991), and the original NRC (2001) approach, and then using the basic NRC (2001) approach but employing the regression equation developed from results of the current study to reestimate the inevitable fecal $\mathrm{P}$ component. To accomplish this, a 700-kg cow consuming $22 \mathrm{~kg}$ of dietary $\mathrm{DM} / \mathrm{d}$ and producing $40 \mathrm{~kg}$ of milk was used as the example animal description. Various animal and dietary characteristics for the different models as described in the original publications were used, including the particular model's own estimate of inevitable fecal $\mathrm{P}$ loss and endogenous urinary $\mathrm{P}$, where appropriate. Estimates of the total dietary $\mathrm{P}$ maintenance requirement were $9.8,20.0,19.3,15.2$, and $23.4 \mathrm{~g}$ of $\mathrm{P} / \mathrm{d}$ based on the ARC (1980), NRC (1989), INRA (1989), AFRC (1991), and the NRC (2001) approaches, respectively. In the NRC (2001) computation inevitable fecal P was 0.8 $\mathrm{g} / \mathrm{kg}$ of $\mathrm{DM}$ and an $\mathrm{AC}$ of 0.8 for dietary $\mathrm{P}$ was used. If an $\mathrm{AC}$ of $0.6,0.7$, or 0.9 were assumed, the total dietary maintenance requirement for $\mathrm{P}$ would be $30.7,26.5$, or $21.0 \mathrm{~g} / \mathrm{cow}$ per day, respectively. By comparison, using the regression equation developed in the current experiment plus the additional $0.002 \mathrm{~g}$ of $\mathrm{P} / \mathrm{kg}$ of $\mathrm{BW}$ (NRC, 2001) to account for the endogenous urinary P, the estimate of total $\mathrm{P}$ requirement for maintenance of this same cow is $25.4 \mathrm{~g} / \mathrm{d}$. In this case, the AC of dietary $\mathrm{P}$ was assumed to be 1.0. Thus, several of the models provided numerically similar estimates for the total dietary maintenance requirement of $\mathrm{P}$ for lactating dairy cows, from 19.3, 20.0, 23.4, to $25.4 \mathrm{~g} / \mathrm{d}$ for the INRA (1989), NRC (1989), NRC (2001) using an AC of 0.8 , and the NRC (2001) approach, but using the new regression equation to estimate inevitable fecal $\mathrm{P}$ developed in the current study. In contrast, the estimates of ARC (1980) and AFRC (1991) were substantially lower. Also, as illustrated by applying different AC for total dietary P to the original NRC (2001) approach, the relative differences in dietary maintenance requirement for $\mathrm{P}$ ranged from 21.0 to $30.7 \mathrm{~g} / \mathrm{cow}$ per day. If one assumes, based on estimates in the literature (e.g., NRC, 2001; Pfeffer et al., 2005), that dietary P in most common feed ingredients for dairy cattle has high absorbability potential and that the $\mathrm{AC}$ will be greatest when dietary $\mathrm{P}$ is fed as close as possible to the true requirement, then utilization will be optimized and risk of excretion into the environment reduced.

\section{CONCLUSIONS}

Inevitable fecal $\mathrm{P}$ excretion $(\mathrm{g} / \mathrm{d})$ divided by $\mathrm{DMI}$ $(\mathrm{kg} / \mathrm{d})$, the approach taken by the NRC (2001) to express the fecal component of the total absorbed $\mathrm{P}$ maintenance requirement for lactating cows, was evaluated. Because in the current experiment $\mathrm{P}$ balance was not different from zero among cows consuming different amounts of DM, measured fecal $\mathrm{P}$ was assumed, by definition, to be inevitable fecal $\mathrm{P}$; that component is the largest part of the $\mathrm{P}$ requirement for maintenance of lactating dairy cows. Endogenous urinary P, the second component of the $\mathrm{P}$ maintenance requirement, was estimated to be small, similar to other studies. The 
NRC (2001) set the fecal component of the absorbed P requirement for maintenance at a constant $0.8 \mathrm{~g}$ of $\mathrm{P} /$ $\mathrm{kg}$ of DMI. This general approach appears to be valid. However, the practical dietary requirement for maintenance $\mathrm{P}$ will be influenced by the $\mathrm{AC}$ for $\mathrm{P}$ applied in that factorial estimation. The question arises, is it appropriate to apply an $\mathrm{AC}$ different than 1.0 to the estimate by the NRC (2001) approach? Based on the results of the current experiment, the inevitable fecal $\mathrm{P}$ associated with the maintenance requirement was refined by development of a regression equation with data over a wide range of DMI, similar to that expected with cows in different stages of lactation and of different BW. The regression equation estimates the inevitable fecal $\mathrm{P}$ component of the $\mathrm{P}$ maintenance requirement as: $(\mathrm{g} / \mathrm{d})=[0.85 \pm 0.070] \times$ DMI $(\mathrm{kg} / \mathrm{d})+[5.30 \pm$ $1.244(\mathrm{~g} / \mathrm{d})]$. In this case, it is assumed that the $\mathrm{AC}$ of $\mathrm{P}$ is 1.0 and further adjustment (e.g., dividing by an AC less than 1.0) is not appropriate. Furthermore, we suggest that the $\mathrm{P}$ in microbial cell debris in feces should be counted as part of inevitable fecal $\mathrm{P}$ and thus the $\mathrm{P}$ maintenance requirement. From the literature, this $\mathrm{P}$ in the microbial fraction is estimated to be as much as two-thirds of the total fecal P loss. Although this idea reaches beyond the classic definition for absorbed $\mathrm{P}$ for maintenance, which theoretically includes only $\mathrm{P}$ that has been absorbed, it fits with the practicality of meeting the animal's need for normal $\mathrm{P}$ maintenance. The microbial population in the digestive tract of ruminants is indispensible for normal digestion of dietary organic matter, synthesis of microbial protein, and for animal survival; these processes must be maintained. The $\mathrm{P}$ requirement of the microbial population in the digestive tract is not taken into account in any other way in current requirement estimates (AFRC, 1991; NRC, 2001).

\section{ACKNOWLEDGMENTS}

The special assistance of the staff at the Michigan State University Dairy Teaching and Research Center to care for the cows is gratefully noted. The biuret was graciously provided by Moorman's Manufacturing Company (Quincy, IL). Partial financial support to conduct the study from the C. E. Meadows Endowment and the Six-State Manure Management Consortium is acknowledged. This study was part of the CSREES/ USDA NC-1119 regional project, "Management Systems to Improve the Economic and Environmental Sustainability of Dairy Enterprises."

\section{REFERENCES}

AFRC (Agricultural and Food Research Council). 1991. AFRC Technical Committee on responses to nutrients, report 6. A reappraisal of the calcium and phosphorous requirements of sheep and cattle. Nutr. Abstr. Rev. Ser. B 61:573-583.

ARC (Agricultural Research Council). 1980. The Nutrient Requirements of Ruminant Livestock. Commonwealth Agricultural Bureaux, Slough, UK.

AOAC. 1990. Page 88 in Official Methods of Analysis; method 965.17. Association of Official Analytical Chemists, Gaithersburg, MD.

Brintrup, R., T. Mooren, U. Meyer, H. Spiekers, and E. Pfeffer. 1993. Effects of two levels of phosphorus intake on performance and faecal phosphorus excretion of dairy cows. J. Anim. Physiol. Anim. Nutr. (Berl.) 69:29-36.

Dairy Records Management Systems. 1999. DHI Glossary. Fact sheet: A-4:9. DRMS, Raleigh, NC.

Fiske, C. H., and Y. Subbarow. 1925. The colorimetric determination of phosphorus. J. Biol. Chem. 63:375-401.

Holter, J. B., and W. E. Urban Jr. 1992. Water partitioning and intake prediction in dry and lactating Holstein cows. J. Dairy Sci. $75: 1472-1479$.

INRA (Institut National de la Recherche Agronomique). 1989. Ruminant Nutrition: Recommended allowances and feed tables. R. Jarrige, ed. John Libbey Eurotext, Paris, France.

Kincaid, R. L., and M. Rodehutscord. 2005. Phosphorus metabolism in the rumen (Chapter 6). Page 190 in Nitrogen and Phosphorus Nutrition of Cattle and the Environment. E. Pfeffer and A. Hristov, ed. CABI Publishing, CAB International, Wallingford, UK.

Knowlton, K. F., and J. H. Herbein. 2002. Phosphorus partitioning during early lactation in dairy cows fed diets varying in phosphorus content. J. Dairy Sci. 85:1227-1236.

Martz, F. A., A. T. Belo, M. F. Weiss, R. L. Belyea, and J. P. Goff. 1990. True absorption of calcium and phosphorus from alfalfa and corn silage when fed to lactation cows. J. Dairy Sci. 73:12881295.

Morse, D., H. H. Head, and C. J. Wilcox. 1992. Disappearance of phosphorus in phytate from concentrates in vitro and from rations fed to lactating dairy cows. J. Dairy Sci. 75:1979-1986.

NRC. 1989. Nutrient Requirements of Dairy Cattle. 6th rev. ed. Natl. Acad. Sci., Washington DC.

NRC. 2001. Nutrient Requirements of Dairy Cattle. 7th rev. ed. Natl. Acad. Sci., Washington DC.

Oba, M., and M. S. Allen. 2000. Effects of brown midrib 3 mutation in corn silage on productivity of dairy cows fed two concentrations of dietary neutral detergent fiber: 3. J. Dairy Sci. 83:1350-1358.

Pfeffer, E., D. K. Beede, and H. Valk. 2005. Phosphorus metabolism in ruminants and requirements of cattle (Chapter 7). Page 220 in Nitrogen and Phosphorus Nutrition of Cattle and the Environment. E. Pfeffer and A. Hristov, ed. CABI Publishing, Wallingford, UK.

SAS Institute. 1999. SAS Software. Release 8.2. SAS Inst. Inc., Cary, NC.

Spiekers, H., R. Brintrup, M. Balmelli, and E. Pfeffer. 1993. Influence of dry matter intake on feacal phosphorus losses in dairy cows fed rations low in phosphorus. J. Anim. Physiol. Anim. Nutr. (Berl.) 69:37-43

Wildman, E. E., G. M. Jones, P. E. Wagner, R. L. Bowman, H. F. Troutt Jr., and T. N. Lesch. 1982. A dairy cow body condition scoring system and its relationship to select production characteristics. J. Dairy Sci. 65:495-501

Williams, C. H., D. J. David, and O. Iismaa. 1962. The determination of chromic oxide in faeces samples by atomic absorption spectrophotometry. J. Agric. Sci. 59:381-385.

Wu, Z., L. D. Satter, A. J. Blohowiak, R. H. Stauffacher, and J. H. Wilson. 2001. Milk production, estimated phosphorus excretion, and bone characteristics of dairy cows fed different amounts of phosphorus for two or three years. J. Dairy Sci. 84:1738-1748.

Wu, Z., L. D. Satter, and R. Sojo. 2000. Milk production, reproductive performance, and fecal excretion of phosphorus by dairy cows fed three amounts of phosphorus. J. Dairy Sci. 83:1028-1041. 